\title{
Anti-aging Effect of Sulfuretin in UVA-irradiated Normal Human Epidermal Keratinocytes
}

\author{
Joong Hyun Shim \\ Faculty of Cosmetics and Beauty Biotechnology, Semyung University, Jecheon-si, Chungcheongbuk-do, Korea
}

Corresponding author: Joong Hyun

Shim, Faculty of Cosmetics and Beauty

Biotechnology, Semyung University, 65

Semyung-ro, Jecheon-si, Chungcheongbuk-

do 27136 , Korea

Tel.: +82436491615

Fax: +82 436491730

Email: jhshim@semyung.ac.kr

Received April 23, 2020

Revised July 10, 2020

Accepted July 22, 2020

Published September 30, 2020

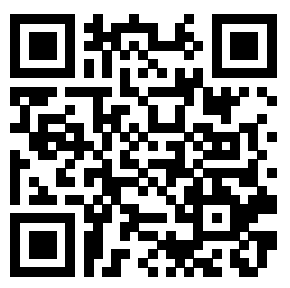

\begin{abstract}
Purpose: This study was carried out to investigate the epidermal moisturizing effects of sulfuretin on normal human epidermal keratinocytes (NHEKs). Methods: Epidermal moisturizing effects of sulfuretin on NHEKs were assessed by quantitative real-time RT-PCR to monitor the expression of genes related to skin hydration, hyaluronic acid (HA)-ELISA assays to detect HA production, and cell viability assays. Results: Sulfuretin increased the mRNA levels of the AQP3/HAS2/KRT1/KRT10 genes and HA production in NHEKs. Conclusion: This study led to the identification of the epidermal moisturizing effects of sulfuretin. The results indicate that sulfuretin can be a potent cosmetic ingredient for skin moisturizing and antiaging products. However, further research is warranted regarding the use of sulfuretin to develop not only cosmetics but also medicines and food.
\end{abstract}

Keywords: Sulfuretin, Hyaluronic acid, AQP3, HAS2, Moisturizing

\section{Introduction}

피부는 신체의 첫번째 방어선 역할을 하며 화학물질, 열, 자외선 (ultra violet, UV) 및 미생물과 같은 다양한 유해 물질로부터 신체 를 보호한다. 피부가 손상을 받게 되면 보호기능이 상실되고 신체는 단기간 내에 이 기능을 회복하기 위하여 새로운 피부를 재생시킨다 (Assefa et al., 2005; Fuchs, 2007).

자외선은 vitamin D3를 생성하도록 유도하거나, 백반증이나 건 선과 같은 특정 질병을 치료하는데 도움을 주는 유익한 작용을 한 다. 하지만 과도한 자외선의 노출은 활성산소종(reactive oxygen species, ROS)을 과도하게 생산하거나 DNA, 지질 및 단백질에 산 화적 손상을 일으키며 피부의 광노화 및 암을 유발하는 것으로 알 려져 있다. 또한 자외선 조사에 따른 산화 스트레스는 $\mathrm{TNF}-\mathrm{a}$ 와 같 은 염증성 싸이토카인의 생성을 유도하고 cytosolic phospholipase A2 (cPLA2)와 cyclooxygenase-2 (COX-2) 등의 발현을 증가시킨 다. 이러한 염증성 반응은 피부의 급성 및 만성 광노화를 유발하고
과도한 색소침착 및 피부건조를 유발한다(Bickers \& Athar, 2006; Fisher et al., 2002).

표피에 존재하는 각질형성세포는 자외선에 노출되면, aquaporin 3 (AQP3)의 발현이 감소되어 피부건조를 야기한다고 알려져 있다 (Cao et al., 2008). AQPs는 소수성을 띄는 세포막에 삽입되어 있는 단백질로, 외부의 수분을 세포 내로 수송하는 막단백질 역할을 담당 하고 있다(Hara-Chikuma et al., 2008; Sougrat et al., 2002). 특 히 인간각질형성세포는 $\mathrm{AQP} 3$ 를 발현하고 있고, 설치류 동물모델에 서의 결과를 살펴보면 AQP3 knock out 마우스는 피부건조, 상처 치유능 저하 등의 결함을 보인다고 보고된바 있다(Sougrat et al., 2002). 또한 세포외기질(extracellular matrix, ECM)의 한 종류인 히알루론산(hyaluronic acid, HA)을 생성하는 효소인 hyaluronan synthase 2 (HAS2)는 각질형성세포에서 자외선에 의하여 발현 이 감소된다는 연구가 있다(Hašová et al., 2011; Park \& Shim, 2016; Shim \& Park, 2017). 자외선에 의해 노화가 유도된 피부 에 히알루론산을 처리하게 되면, 노화현상을 경감시키는 역할을 한 
다. 또한 자외선은 표피 기저층의 각질형성세포를 과분화 및 과각 질화시켜 피부의 노화를 유도하는데, 기저층의 각질형성세포가 발 현하는 keratin 5 (KRT5), keratin 14 (KRT14)의 발현을 감소시키 고 filaggrin $(F L G)$, loricrin $(L O R)$, keratin 1 (KRT1), keratin 10 (KRT10) 등의 유전자 발현을 증가시킨다고 알려져 있다(Shim \& Park, 2017; Eckert et al., 2005).

여러 연구에 따르면 천연 산화방지제와 플라보노이드 및 안토시 아닌과 같은 소재가 항염증 및 광노화를 억제하는 효과가 있음이 보 고되었다. Sulfuretin은 Rhus veriniciflua 식물에서 추출되는 플라 보노이드 성분으로 강력한 항산화 효과를 지니며 인간유래 HepG2 세포에서 $\mathrm{t}-\mathrm{BHP}$ 로 유도된 산화손상에 대한 호보효과가 있다고 알 려져 있다(Lee et al., 2014). 또한 류마티스 관절염을 지연시키거나 예방하는 효과가 있으며 Fas 매개 caspase-8 의존경로에 의한 세 포사멸을 유도하여 백혈병에 효과가 있다고 보고되었다(Figure 1A; Choi et al., 2003; Lee et al., 2012b; Lee et al., 2012a).

Sulfuretin이 인간각질형성세포에서 피부노화 개선과 피부보습 등에 효과가 있는지에 대한 연구는 미흡한 실정이다. 본 연구에서는 sulfuretin의 보습능과 관련되어 $A Q P 3$ 와 $H A S 2$ 유전자의 발현에 끼치는 영향을 확인해 보고, 자외선에 의해 감소된 normal human epidermal keratinocytes (NHEKs)의 HA 생산 능력이 sulfuretin 에 의해 증가되는지 입증하고자 한다. 또한 자외선에 의해 과분화/ 과각질화가 유도된 상태에서 sulfuretin의 과분화/과각질화를 억제 할 수 있는 효능이 있는지 확인하고자 한다.

\section{Methods}

\section{1. 실험재료 및 세포배양}

본 연구에서 사용된 sulfuretin은 ChemFaces (China; CFN97844, Purity $\geq 98 \%$ )에서 구매하여 사용하였다. Sulfuretin 의 효능평가를 위하여 사용된 normal human epidermal keratinocytes (NHEKs)와 배지인 KGM-gold bulletKit은 Lonza (Sweden)에서 구입하였다. NHEKs는 습도 $100 \%, 37^{\circ} \mathrm{C}, 5 \% \mathrm{CO}_{2}$ 의 조건으로 세포배양기에서 배양하였다.

\section{2. 자외선 조사}

Ultraviolet A (UVA) 조사로 인한 NHEKs의 노화를 부여하기 위 해서 다음과 같은 조건으로 $\mathrm{UVA}$ 를 처리하였다. NHEKs가 배양되 고 있는 $35 \pi$ 조직배양접시에 DMEM (phenol red free; Welgene, Korea)을 접종한 후, 자외선 조사기(BioLink; Vilber Lourmat, France)를 사용하여 $3 \mathrm{~J} / \mathrm{cm}^{2}$ 의 UVA를 조사하였다(Shim \& Park, 2017; Shim, 2018).

\section{3. 세포 생존율 분석}

NHEKs의 생존율은 cell counting kit-8 (CCK-8; DoGenBio, Korea) assay를 이용하였다. NHEKs를 배양접시에 접종한 후, phenol red free-DMEM에 sulfuretin을 농도 별로 희석하여 처리 하였다. NHEKs에 시료를 농도 별로 $24 \mathrm{~h}$ 처리한 후 CCK-8 시약 을 phenol red free-DMEM에 $1 / 10$ 로 희석하여 세포에 접종한 후 1 $\mathrm{h}$ 동안 세포배양기에서 반응시켰다. CCK-8 assay는 $450 \mathrm{~nm}$ 의 흡 광도를 측정하였고(Epoch; Biotek, USA), 세포를 배양하지 않고 배 지만 넣은 대조군의 흡광도를 blank로 보정하여 세포 생존율을 산출 하였다.

\section{RNA 추출 및 실시간 유전자 중합효소 연쇄반응(real-time RT-PCR)}

TRIzol reagent (Invitrogen, USA)를 사용하여 total RNA를 추 출하였다. SuperiorScript III Master Mix (Enzynomix, Korea)를 이용하여 RNA로부터 complement DNA를 합성하였으며, 인간각질 형성세포의 표지인자 발현양상을 비교하기 위하여 real-time RTPCR (StepOnePlus; Applied Biotechnologies, USA)을 진행하였 다(Shim, 2019). 실험에 사용된 특정 Taqman Gene expression assay (Applied Biotechnologies, USA)는 Table 1에 명기하였다.

\section{5. 히알루론산-효소결합 면역흡착법(Enzyme-linked immunosorbent assay; HA-ELISA)}

Sulfuretin에 의한 히알루론산 생성 정도를 확인하기 위하여 $\mathrm{NHEKs}$ 를 $24 \mathrm{~h}$ 동안 세포배양기에서 배양한 후, UVA $\left(3 \mathrm{~J} / \mathrm{cm}^{2}\right)$ 를 조사하였다. 자외선 조사 후 sulfuretin을 처리하여 세포배양기에서

Table 1. Gene symbol, name and Assay ID Number in real-time RT-PCR Analysis

\begin{tabular}{llr}
\hline Gene symbol & \multicolumn{1}{c}{ Gene name } & Assay ID \\
AQP3 & Aquaporin 3 & Hs01105469_g1 \\
HAS2 & Hyaluronan synthase 2 & Hs003435_m1 \\
FLG & Filaggrin & Hs01894962_s1 \\
LOR & Loricrin & Hs01549614_g1 \\
KRT1 & Keratin 1 & Hs01043114_g1 \\
KRT10 & Keratin 10 & 43333764F \\
GAPDH & Glyceraldehyde-3-phosphate dehydrogenase &
\end{tabular}


A

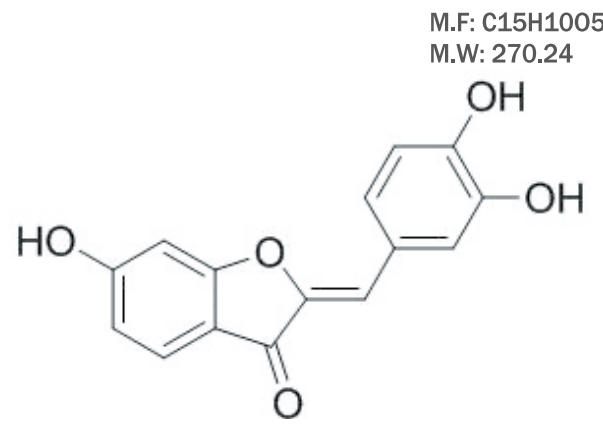

Chemical structure of sulfuretin
B

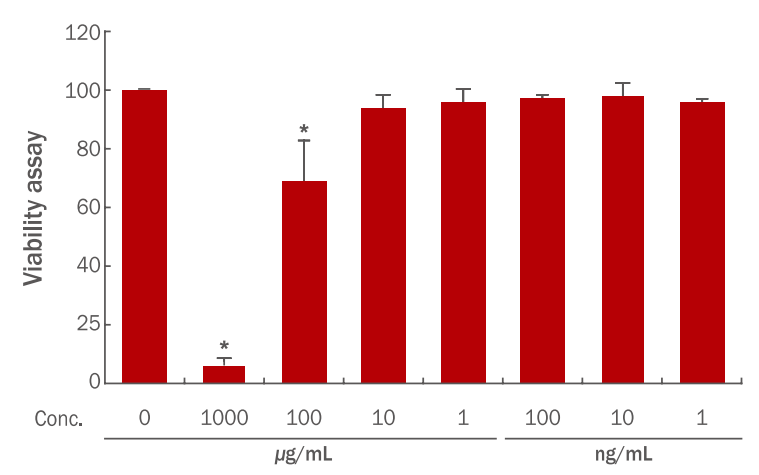

Figure 1. Chemical structure of sulfuretin and cytotoxicity of sulfuretin in normal human epidermal keratinocytes (NHEKs).

(A) The chemical structure of sulfuretin. (B) Cytotoxicity of sulfuretin. NHEKs $\left(2 \times 10^{4}\right.$ cells) were seeded in 96-well cell culture plate and treated indicated concentration of sulfuretin for $24 \mathrm{~h}$. Cell viability was measured by CCK-8 assay. The results are presented as the mean \pm S.D. of the percentage of control optical density in triplicate. ${ }^{*}$ means compared to control ${ }^{*} p<0.05$.

A

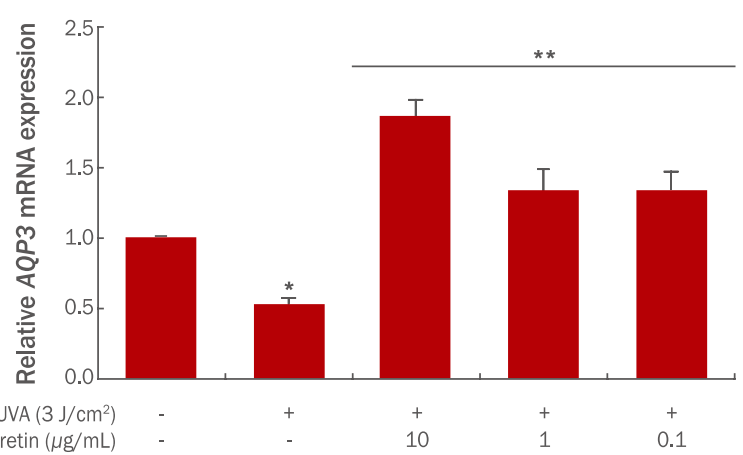

B

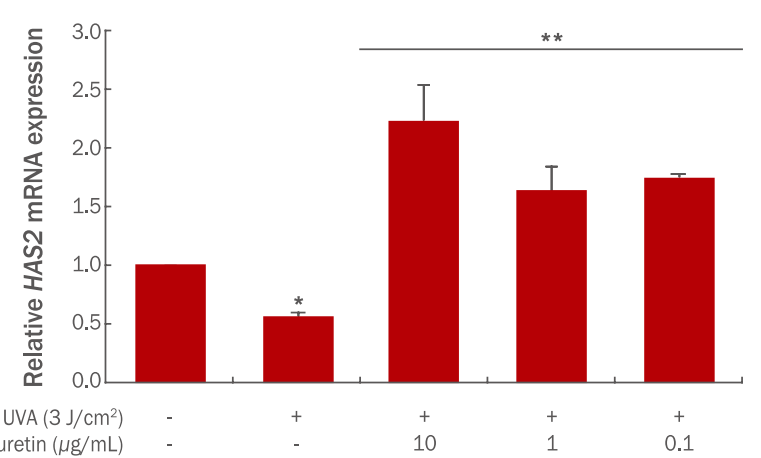

Figure 2. Characterization of sulfuretin treatment on UVA-irradiated NHEKs.

Real-time RT-PCR analysis of the NHEKs markers, AQP3 (A), and HAS2 (B). Values represent the mean \pm S.D. of three independent experiments. ${ }^{*}$ means compared to control, ${ }^{* *}$ means compared to UVA-irradiated condition ${ }^{*},{ }^{* *} p<0.05$.

$48 \mathrm{~h}$ 동안 유지하였다. 배양액 내의 HA 단백질의 양은 Hyaluronic acid-ELISA kit (HA-ELISA; Corgenix, USA)를 이용하여 측정하 였다.

\section{6. 통계분석}

본 연구에서의 통계처리는 Students $t$-test법을 사용하여 유의 수준 $0.05(p<0.05)$ 로 하여 검정하였다.

\section{Results and Discussion}

\section{NHEKs에서 sulfuretin의 농도별 생존율 분석}

NHEKs에 대한 sulfuretin의 세포독성을 확인하기 위하여 cell counting kit-8 (CCK-8) assay를 수행하였다. 대조군은 시료를 처 리하지 않았고 sulfuretin는 각각 $1,10,100 \mathrm{ng} / \mathrm{mL}, 1,10,100$, $1000 \mu \mathrm{g} / \mathrm{mL}$ 의 농도로 처리하여 NHEKs의 생존율을 측정하였다. Sulfuretin을 $100 \mu \mathrm{g} / \mathrm{mL}$ 농도 이상으로 처리할 때 NHEKs의 생존
율이 유의성 있게 감소함을 확인하였다(Figure 1B). $10 \mu \mathrm{g} / \mathrm{mL}$ 의 농 도에서 NHEKs의 생존율이 무처리군과 유사함을 확인하여 본 실험 에서는 $0.1,1,10 \mu \mathrm{g} / \mathrm{mL}$ 의 sulfuretin을 처리하여 추후 실험을 진 행하였다.

\section{2. 자외선 조사와 sulfuretin 처리에 따른 NHEKs의 mRNA 발현}

$\mathrm{NHEKs}$ 에 $3 \mathrm{~J} / \mathrm{cm}^{2}$ 의 UVA를 조사한 후, sulfuretin를 농도별로 $24 \mathrm{~h}$ 처리하여 NHEKs가 발현하는 표지인자인 $A Q P 3$ 와 HAS2 유 전자의 발현양을 Real-time RT-PCR을 통하여 확인하였다. AQP3 와 HAS2는 각질형성세포가 발현하는 유전자로 세포 외부의 수분을 세포 내부로 이동시키거나 피부 표피 내에 수분을 보존하는 역할을 담당하며 보습에 관여하는 표지인자로 알려져 있다(Park \& Shim, 2016; Shim \& Park, 2017). UVA 조사에 의해 NHEKs는 AQP3, $H A S 2$ 와 같은 보습인자 발현이 대조군 대비 각각 $53 \%, 57 \%$ 로 유의 성 있게 감소하였다. Real-time RT-PCR을 통해 sulfuretin를 처 리한 $\mathrm{NHEKs}$ 에서의 $A Q P 3$ 와 $H A S 2$ 의 발현을 확인한 결과, UVA 조 사군 대비 $10 \mu \mathrm{g} / \mathrm{mL}$ 의 sulfuretin 처리군에서 $A Q P 3$ 의 발현이 3.5 


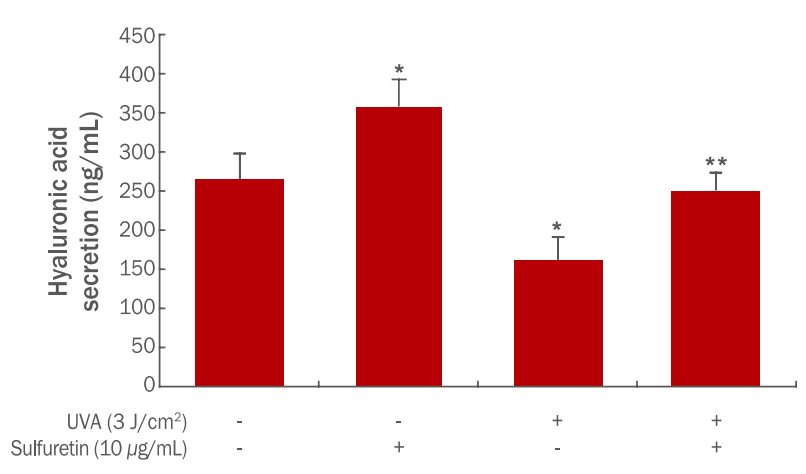

Figure 3. Effects of sulfuretin on hyaluronic acid (HA) protein synthesis in NHEKs.

NHEKs $\left(2 \times 10^{5}\right.$ cells) were seeded in $60 \mathrm{~mm}$ tissue culture dish, treated with sulfuretin for $48 \mathrm{~h}$. And medium of the cell were collected and analyzed for HA-ELISA. The data represent the mean \pm S.D. of three independent experiments. *means compared to control, ** means compared to UVA-irradiated condition *, ${ }^{* *} p<0.05$.

배, $H A S 2$ 의 발현이 3.9 배 가량 증가하는 유의성 있는 효과를 보였 다(Figure $2 \mathrm{~A}, \mathrm{~B}$ ). 세포 외부의 수분을 세포 내부로 수송하는 $A Q P 3$ 과 히알루론산(hyaluronic acid, HA)를 생성하는 효소인 HAS2의 발 현을 증가시키는 현상을 통해, sulfuretin가 피부보습에 효과가 있 는 것으로 사료된다(Hara-Chikuma et al., 2008; Hašová et al., 2011; Sougrat et al., 2002).

\section{Sulfuretin의 히알루론산 생성 촉진 효과}

$\mathrm{HAS} 2$ 는 각질형성세포에서 히알루론산을 생성하는데 중요한 역할을 하는 효소로 알려져 있다(Karvinen et al., 2003; Kim et al., 2004). Sulfuretin를 처리하여 HAS2 유전자의 발현이 증가된 $\mathrm{NHEKs}$ 에서 HAS2의 대사산물인 히알루론산 단백질의 생성 역시 증가되는지를 알아보기 위해 히알루론산에 대한 효소결합 면역흡착 법(enzyme-linked immunosorbent assay, ELISA)을 이용하여 확 인하였다(Figure 3). 실험결과, UVA 조사에 의해 $39 \%$ 가량 생성이 감소되었던 히알루론산이 sulfuretin 처리에 의해 UVA 조사군 대비 $55 \%$ 가량 유의성 있게 증가함을 확인하였다. 본 결과는 real-time $\mathrm{RT}-\mathrm{PCR}$ 의 $H A S 2$ 유전자 발현에 대한 실험 결과와 일관성이 있으 며, sulfuretin는 HAS2 유전자 발현 뿐만 아니라, HAS2 유전자 발 현에 의한 최종 대사산물인 히알루론산 단백질의 생성 역시 증가시 킬 수 있음을 보여준다.

\section{Sulfuretin의 표피 분화마커 발현에 대한 효과}

기저층에 존재하는 각질형성세포는 분화과정을 거치면서 각질층 으로 이동하여 최종적으로 각질층에서 탈락되는 각질턴오버를 거친 다. 기저층의 각질형성세포가 유극층, 과립층, 각질층으로 순차적
으로 분화가 되면서 기저층의 각질형성세포가 발현하는 표지인자인 $K R T 5, K R T 14$ 등의 유전자 발현이 감소하고, 각질형성세포 분화마 커인 $F L G, L O R, K R T 1, K R T 10$ 과 같은 유전자의 발현은 증가한다 고 알려져 있다(Eckert et al., 2005). 따라서 기저층의 각질형성세포 표지인자로 $\mathrm{KRT} 5 / 14$ 등의 유전자가 표지인자로 활용되고, 과립층 과 유극층으로 분화 중인 각질형성세포는 $F L G, L O R, K R T 1 / 10$ 등 의 유전자가 표지인자로 사용된다. 표피층이 자외선 등과 같은 외인 성 노화, 구체적으로 광노화가 유도하는 자극을 받게 되면 각질형성 세포의 분화가 촉진되어 과분화/과각질화가 유도된다. 본 실험에서 는 NHEKs에 UVA $\left(3 \mathrm{~J} / \mathrm{cm}^{2}\right)$ 를 조사하여 $\mathrm{NHEKs}$ 의 과분화/과각질 화를 유도한 상태에서 sulfuretin를 처리했을 때, 분화된 인간각질형 성세포의 표지인자인 FLG, LOR, KRT1/10 유전자의 발현을 realtime RT-PCR법으로 확인하였다. 위의 4 가지 표지인자 중 자외선에 의해 FLG, KRT1, KRT10의 발현이 유의성 있게 증가하였고 $L O R$ 의 발현에는 큰 영향을 미치지 않았다(Park \& Shim, 2016; Shim \& Park, 2017). UVA에 의해 과분화/과각질화가 유도된 NHEKs에 sulfuretin를 처리한 후 FLG의 유전자발현 양상을 확인한 결과 1 , $10 \mu \mathrm{g} / \mathrm{mL}$ 농도의 sulfuretin은 FLG의 발현을 감소시키지 못하였지 만 $0.1 \mu \mathrm{g} / \mathrm{ml}$ 의 농도의 sulfuretin에 의해 $43 \%$ 의 발현을 유의성 있 게 감소시킴을 확인할 수 있었다(Figure 4A). KRT1 유전자는 UVA 처리군 대비 $10,1,0.1 \mu \mathrm{g} / \mathrm{mL}$ 의 농도의 sulfuretin에 의하여 각 각 $91,90,85 \%$ 유의성 있게 감소하였고, $K R T 10$ 유전자의 경우에 는 $0.1,1,10 \mu \mathrm{g} / \mathrm{mL}$ 의 농도의 sulfuretin 처리군에서 각각 39,37 , $43 \%$ 가량 유의성 있게 감소됨을 확인할 수 있다(Figure 4C, D). 반 면 $L O R$ 은 sulfuretin에 의해 특이적인 발현의 차이는 보이지 않았 다. 본 결과는 UVA가 각질형성세포의 과분화/과각질화를 유발하지 만, sulfuretin가 FLG, KRT1, KRT10의 발현을 감소시켜 과도한 분 화를 억제시켜 광노화의 영향을 감소시킬 수 있음을 보여주고 있다.

\section{$\overline{\text { Conclusion }}$}

피부노화의 증상으로 과각질화에 의한 각질층이 두꺼워지고, 염 증이 증가하거나주름이 증가하는 등의 현상이 나타나게 된다. 자외 선, 미세먼지 등과 같은 외부환경인자에 의해 피부세포 내 활성산소 종의 연쇄 반응을 통해 노화가 촉진되고 피부질환이 야기된다(Kim et al., 2011; Talwar et al., 1995). 또한 노화는 생체 내 존재하는 세포의 감소, 기능저하에 의해 정상적인 기능을 하는 조직으로의 재 생, 기능을 하지 못하게 된다(Jones \& Rando, 2011; Kirkwood, 2005).

본 연구를 바탕으로 sulfuretin를 NHEKs에 처리할 적정 처리 농 도를 확인할 수 있었다. $10 \mu \mathrm{g} / \mathrm{mL}$ 이하의 농도에서 NHEKs 세포 의 생존율에 영향을 미치지 않음을 Figure $1 \mathrm{~B}$ 를 통해 확인하였다. $A Q P 3$ 과 $H A S 2$ 유전자의 발현과 히알루론산 단백질 생성 측정에서 
A
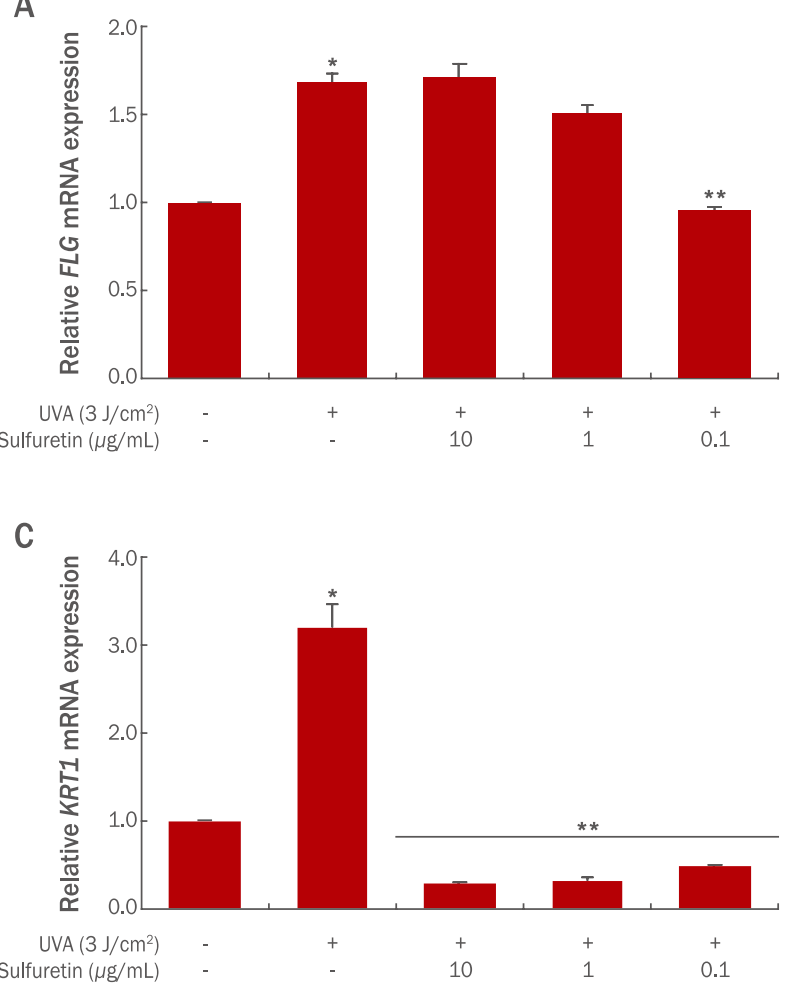

B

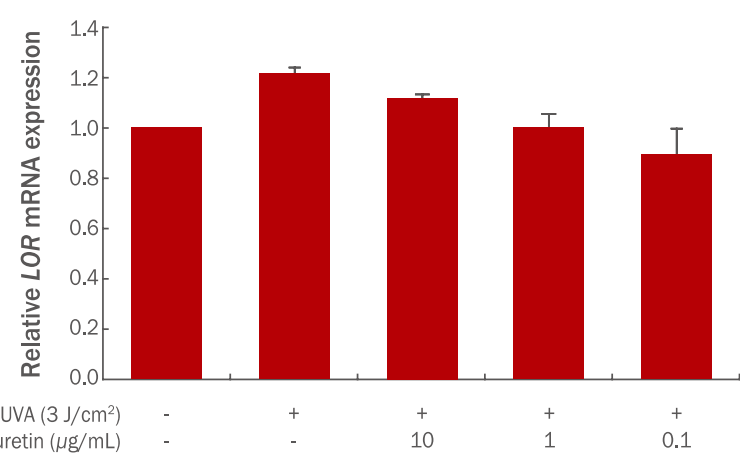

D

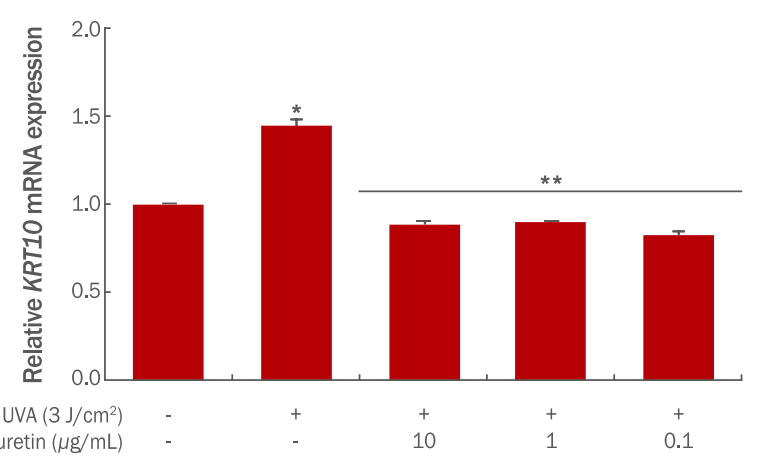

Figure 4. Differentiated marker expression of sulfuretin treatment on UVA-irradiated NHEKs.

Real-time RT-PCR analysis of the representative differentiated markers, FLG (A), LOR (B), KRT1 (C) and KRT1O (D). The graphs are shown as the mean \pm S.D. of three independent experiments. "means compared to control, ${ }^{* *}$ means compared to UVA-irradiated condition *, ${ }^{* *} p<0.05$.

sulfuretin가 유의성 있게 UVA에 의해 감소된 보습인자의 발현을 회 복시키는 결과를 나타내었다(Figure 2,3). 추가적으로 sulfuretin는 $\mathrm{UVA}$ 조사에 의해 증가된 $F L G, K R T 1$ 과 $K R T 10$ 의 유전자 발현을 유의성있게 낮춤으로 NHEKs의 과분화/과각질화를 억제시키는 능 력이 있음을 확인할 수 있었다(Figure 4). 이는 sulfuretin가 피부 보 습을 개선하는 후보물질로서의 가능성을 시사한다.

Sulfuretin의 피부 보습 효과를 확인한 결과는 본 연구가 최초로, 추후 기능성 화장품 및 의약품에 실질적으로 응용이 될 수 있고 피 부노화를 개선할 수 있는 가능성을 보여주었다고 사료된다. 향후 sulfuretin이 자외선에 의해 노화된 피부를 개선하는 기전에 대한 추 가연구와 본 소재를 이용한 심도 있는 임상연구가 진행될 필요가 있 을 것으로 보인다.

\section{Acknowledgements}

이 논문은 2020 학년도 세명대학교 교내학술연구비 지원에 의 해 수행된 연구임.

\section{Author's contribution}

JHS designed, performed experiments, analyzed data, and wrote the manuscript. All figures are created by the author.

\section{Author details}

Joong Hyun Shim (Professor), Faculty of Cosmetics and Beauty Biotechnology, Semyung University, 65 Semyungro, Jecheon-si, Chungcheongbuk-do 27136, Korea

\section{References}

Assefa Z, Van Laethem A, Garmyn M, Agostinis P. Ultraviolet radiation-induced apoptosis in keratinocytes: on the role of cytosolic factors. Biochimica et Biophysica Acta, 1755: 90-106, 2005.

Bickers DR, Athar M. Oxidative stress in the pathogenesis of skin disease. Journal of Investigative Dermatology, 126: 256-275, 2006.

Cao C, Wan S, Jiang Q, Amaral A, Lu S, Hu G, Bi Z, Kouttab N, Chu W, Wan Y. All-trans retinoic acid attenuates ultraviolet 
radiation-induced down-regulation of aquaporin-3 and water permeability in human keratinocytes. Journal of Cellular Physiology, 215: 506-516, 2008.

Choi J, Yoon BJ, Han YN, Lee KT, Ha J, Jung HJ, Park HJ. Antirheumatoid arthritis effect of Rhus verniciflua and of the active component, sulfuretin. Planta Medica, 69: 899-904, 2003.

Eckert RL, Sturniolo MT, Broome AM, Ruse M, Rorke EA. Transglutaminase function in epidermis. Journal of Investigative Dermatology, 124: 481-492, 2005.

Fisher GJ, Kang S, Varani J, Bata-Csorgo Z, Wan Y, Datta $\mathrm{S}$, Voorhees JJ. Mechanisms of photoaging and chronological skin aging. Archives of Dermatology, 138: 1462-1470, 2002.

Fuchs E. Scratching the surface of skin development. Nature, 22: 834-842, 2007.

Hara-Chikuma M, Verkman AS. Roles of aquaporin-3 in the epidermis. Journal of Investigative Dermatology, 128: 2145-2151, 2008.

Hašová M, Crhák T, Safránková B, Dvořáková J, Muthný T, Velebný V, Kubala L. Hyaluronan minimizes effects of UV irradiation on human keratinocytes. Archives of Dermatological Research, 303: 277-284, 2011.

Jones DL, Rando TA. Emerging models and paradigms for stem cell ageing. Nature Cell Biology, 13: 506-512, 2011.

Karvinen S, Pasonen-Seppänen S, Hyttinen JM, Pienimäki JP, Törrönen K, Jokela TA, Tammi MI, Tammi R. Keratinocyte growth factor stimulates migration and hyaluronan synthesis in the epidermis by activation of keratinocyte hyaluronan synthases 2 and 3. The Journal of Biological Chemistry, 278: 49495-49504, 2003.

Kim J, Lee CW, Kim EK, Lee SJ, Park NH, Kim HS, Kim HK, Char K, Jang YP, Kim JW. Inhibition effect of Gynura procumbens extract on UV-B-induced matrixmetalloproteinase expression in human dermal fibroblasts. Journal of Ethnopharmacology, 137: 427433, 2011.

Kim S, Kang BY, Cho SY, Sung DS, Chang HK, Yeom MH, Kim $\mathrm{DH}$, Sim YC, Lee YS. Compound $\mathrm{K}$ induces expression of hyaluronan synthase 2 gene in transformed human keratinocytes and increases hyaluronan in hairless mouse skin. Biochemical and Biophysical Research
Communication, 316: 348-355, 2004.

Kirkwood TB. Understanding the odd science of aging. Cell, 120: 437-447, 2005.

Lee DS, Kim KS, Ko W, Li B, Jeong GS, Jang JH, Oh H, Kim YC. The cytoprotective effect of sulfuretin against tert-butyl hydroperoxide-induced hepatotoxicity through Nrf2/ ARE and JNK/ERK MAPK-mediated heme oxygenase-1 expression. International Journal of Molecular Sciences, 19: 8863-8877, 2014.

Lee KW, Chung KS, Seo JH, Yim SV, Park HJ, Choi JH, Lee KT. Sulfuretin from heartwood of Rhus verniciflua triggers apoptosis through activation of Fas, Caspase-8, and the mitochondrial death pathway in $\mathrm{HL}-60$ human leukemia cells. Journal of Cellular Biochemistry, 113: 2835-2844, 2012.

Lee YR, Hwang JK, Koh HW, Jang KY, Lee JH, Park JW, Park $\mathrm{BH}$. Sulfuretin, a major flavonoid isolated from Rhus verniciflua, ameliorates experimental arthritis in mice. Life Science, 90: 799-807, 2012.

Park SY, Shim JH. Anti-aging effect of Psoraleae fructus extract in UVA-irradiated HaCaT cells. Asian Journal of Beauty and Cosmetology, 14: 119-126, 2016.

Shim JH, Park SY. Anti-aging effect of Diospyros Kaki Thunb extracts in UVA-irradiated epidermal keratinocytes. Asian Journal of Beauty and Cosmetology, 15: 170-178, 2017.

Shim JH. Human dermal stem/progenitor cell-derived conditioned medium ameliorates ultraviolet a-induced damage of normal human epidermal keratinocytes. Asian Journal of Beauty and Cosmetology, 16: 42-51, 2018.

Shim JH. Anti-inflammatory effect of zeaxanthin in RAW264.7 cells. Asian Journal of Beauty and Cosmetology, 17: 431439, 2019.

Sougrat R, Morand M, Gondran C, Barré P, Gobin R, Bonté F, Dumas M, Verbavatz JM. Functional expression of AQP3 in human skin epidermis and reconstructed epidermis. The Journal of Investigative Dermatology, 118: 678-685, 2002.

Talwar HS, Griffiths CE, Fisher GJ, Hamilton TA, Voorhees JJ. Reduced type I and type III procollagens in photodamaged adult human skin. The Journal of Investigative Dermatology, 105: 285-290, 1995. 


\section{국문초록}

\section{자외선 조사에 의해 노화된 인간각질형성세포에서 sulfuretin의 항노화 효능}

심중현

세명대학교 화장품뷰티생명공학부 피부기초과학연구실, 충청북도 제천시, 한국

목적: 본 연구는 sulfuretin이 자외선에 의해 광노화가 유도된 인간각질형성세포의 항노화 효능을 확인하기 위하여 수행되었다. 방 법: 자외선으로 노화를 유도한 인각각질형성세포에서 sulfuretin의 보습효과를 확인하기 위하여 세포생존율, 보습에 관련된 유전자 발현양상, 히알루론산 단백질의 발현 정도를 확인하였다. 결과: Sufuretin의 항노화 효능을 확인하기 위하여 $A Q P 3, H A S 2, F L G$, $K R T 1, K R T 10$ 의 유전자 발현을 확인한 결과, 자외선 조사에 의해 감소한 $A Q P 3$ 와 $H A S 2$ 유전자의 발현이 sulfuretin에 의해 증가 하였다. 인각각질형성세포의 과각질화를 유도하는 $K R T 1$ 과 $K R T 10$ 과 과분화의 표지인자인 $F L G$ 의 발현이 sufuretin에 의해 감소 하였다. 또한 히알루론산 단백질의 생성이 sulfuretin에 의해 증가함을 확인하였다. 결론: 본 연구를 통해 sulfuretin의 항노화 효능 을 확인하였고, 향후 sulfuretin이 화장품 및 의약품과 건강식품의 개발에 활용할 수 있는 소재로서의 가능성을 확인하기 위해 심도 있는 추가연구가 필요할 것으로 사료된다.

핵심어: Sulfuretin, 히알루론산, $A Q P 3, H A S 2$, 보습

이 논문은 2020학년도 세명대학교 교내학술연구비 지원에 의해 수행된 연구임.

\section{참고문헌}

박선영, 심중현. 자외선 조사에 의해 노화된 $\mathrm{HaCaT}$ 세포에서 보골지 추출물의 항노화 효능. 아시안뷰티화장품학술지, 14: 119-126, 2016.

심중현, 박선영. 자외선 조사에 의해 노화된 인간각질형성세포에서 감잎 추출물의 항노화 효능. 아시안뷰티화장품학술지, 15: 170-178, 2017.

심중현. 인간 진피유래 줄기세포 배양액에 의한 인각각질형성세포의 노화 개선 효과. 아시안뷰티화장품학술지, $16: 42-$ $51,2018$.

심중현, 제아잔틴에 의한 RAW264.7 세포에서의 항염 효과. 아시안뷰티화장품학술지, 17: 431-439, 2019. 


\section{中文摘要}

\section{Sulfuretin对UVA照射的人表皮角质形成细胞的抗衰老作用}

沁重鉉

世明大学化妆品美容生命工学科 皮肤基础科学研究室，忠淸北道提川市，韩国

目的: 进行这项研究是为了研究sulfuretin对正常人表皮角质形成细胞（NHEKs）的表皮保湿作用。方法: 通过 定量实时RT-PCR评估sulfuretin对NHEKs的表皮保湿作用, 以监测与皮肤水合作用相关的基因的表达, 采用透 明质酸 (HA)-ELISA测定法检测HA产生, 并进行细胞存活率测定。结果: Sulfuretin增加了NHEKs中AQP3/HAS2 IKRT1/KRT10基因的mRNA水平和HA的产生。结论: 本研究鉴定了Sulfuretin的表皮保湿作用。结果表明, sulfuretin可以作为皮肤保湿和抗衰老产品的有效化妆品成分。但是, 需要进一步研究Sulfuretin的用途, 以开 发化妆品，药物和食品。

关键词: Sulfuretin，透明质酸, $A Q P 3, H A S 2$, 保湿 